\title{
RARE CERVICAL SPINE NEUROENTERIC IDEM CYST WITH INTRAMEDULLARY EXTENSION
}

\author{
Gulzar Gupta1, Chetan Wadhwa², Rajveer Garg33, R. K. Kaushal ${ }^{4}$
}

${ }^{1}$ Associate Professor, Department of Neurosurgery, Dayanand Medical College, Ludhiana.

${ }^{2}$ Senior Resident, Department of Neurosurgery, Dayanand Medical College, Ludhiana.

${ }_{3}^{3}$ Senior Resident, Department of Neurosurgery, Dayanand Medical College, Ludhiana.

${ }^{4}$ Professor \& HOD, Department of Neurosurgery, Dayanand Medical College, Ludhiana.

\begin{abstract}
He had gradually progressive neurological deterioration in the form of quadriparesis. MRI was suggestive of cervical cord SOL. The clinical, radiological, and surgical findings are discussed together with a brief critical review of the literature. The patient had no other associated anomalies. The intradural extramedullary component of cyst was removed totally with debulking of intramedullary part with good neurological recovery. The clinical presentation was rather atypical for neurenteric cyst. Neurenteric cyst should be considered in the differential diagnosis of an intradural mass lesion regardless of the age, clinical presentation or location of the lesion.
\end{abstract}

KEYWORDS: Neurenteric Cyst, Enterogenous Cyst and Cervical Spine.

HOW TO CITE THIS ARTICLE: Gulzar Gupta, Chetan Wadhwa, Rajveer Garg, R. K. Kaushal. "Rare Cervical Spine Neuroenteric Idem Cyst with Intramedullary Extension". Journal of Evolution of Medical and Dental Sciences 2015; Vol. 4, Issue 92, November 16; Page: 15813-15816, DOI: $10.14260 /$ jemds/2015/2289.

INTRODUCTION: Intraspinal neurenteric cysts are rare and account for only $0.3-0.5 \%$ of all spinal tumours.[1] The first histologically confirmed endodermal cyst was reported by Puusepp in 1934, he called it intestinoma.[2] This pathological entity was reported under a variety of terms, including; enteric cyst.[3] neurenteric cyst. [4] enterogenous cyst.[5] gastrocytoma.[6] and teratomatous cyst. [5] One reason for the confusion in naming these cysts is that they are not uniform; likely they exist as a spectrum of lesions which range from a simple isolated intraspinal cyst with no other abnormalities to the so-called split notochord syndrome, in which there may be multiple visceral and vertebral anomalies. [7]

Spinal neurenteric cysts are infrequently reported congenital abnormalities that are believed to be derived from an abnormal connection between the primitive endoderm and ectoderm during the 3rd week of life. Neurenteric cysts are not confined to the spinal column and may be found within the brain, mediastinum, abdomen, pelvis, or even in a subcutaneous location. $[8,9,10,11,12,13,14]$

CASE REPORT: This was a 56-year-old male patient who complained of neck pain with radiation to rt upper limb for about 3 years. He presented to the OPD with complaint of gradually progressive weakness of the upper and lower limbs. Patient was continent.

On admission, his neurological examination revealed quadriparesis grade 3-4 motor power with exaggerated deep tendon jerks and bilateral extensor planter response. He had impairment of position and vibration sense in lower limbs.

Financial or Other, Competing Interest: None.

Submission 26-09-2015, Peer Review 29-09-2015,

Acceptance 05-11-2015, Published 16-11-2015.

Corresponding Author:

Dr. Chetan Wadhwa,

Room No. 49, PG Hostel,

Dayanand Medical College,

Ludhiana.

E-mail: chetan22989@gmail.com

DOI:10.14260/jemds/2015/2289.
Magnetic resonance imaging [MRI] of cervical spine showed a well-defined intradural extramedullary soft tissue mass lesion at the level of C5-C6, markedly compressing the spinal cord from its posterior aspect. The lesion had a cystic component and measured $2.5 \times 1.5 \mathrm{~cm}$ in diameter. There was moderate enhancement after IV contrast. The vertebrae appeared normal on imaging studies [Fig. 1].

The patient underwent surgical excision of the mass lesion through a cervical laminectomy [C3-C7]. The lesion was found posterior to the spinal cord with extramedullary component with intramedullary extension. It was pale, whitish grey in colour, with few blood vessels on the surface.

There was a small cystic component that contained yellowish thick fluid. The cyst was attached to the dorsal surface of the spinal cord, the intradural extramedullary component was dissected carefully and excised completely and debulking of intramedullary extension done but capsule left behind which was adherent to cord as there was evidence of invasion of the cord. The patient showed remarkable improvement in his neurological condition in the immediate post-operative period.

Histological examination demonstrated a cyst lined by respiratory type epithelium with underlying seromucinousglands, smooth muscle fibres and cartilage. The wall was infiltrated by inflammatory cells and sheets of macrophages some of which were foamy [Fig. 3]. The case was diagnosed as neurenteric cyst.

DISCUSSION: Puusepp reported the first histologically confirmed intraspinal neurenteric cyst in 1934.[2] Angoli, et al reviewed 33 reported cases of histologically identified intraspinal neurenteric cysts; 18 of them were in the cervicothoracic spine between C3 and T7. Eighty-percent were intradural extramedullary and $12 \%$ were intramedullary.[15] Neurenteric cysts were also reported intracranially.[16,17] and craniospinal cyst were also reported.[18] The embryological basis for the formation of neurenteric cyst was reviewed by several authors. 
The notochordal plate is interposed between the foregut and the neuroectoderm during the 3rd week of embryonic life. The notochord may split if there were an accessory neurenteric canal or if adhesions occurred between the neuroectoderm and the endoderm following their previous close contact. $[15,19,20,21,22]$ On the other hand, some authors regard this process as a primary splitting of the notochord resulting from incomplete or faulty escalation of the notochord.

The intraspinal neurenteric cysts may occur without vertebral body abnormality. In the review of 33 cases of neurenteric cyst by Agnoli, et al, vertebral anomalies wereverified in a minority of cases [Only in 9 of the 33]. Other authors also reported that these cysts can be isolatedintradurally without any associated anomalies of the vertebrae and alimentary canal.[15,23]

Nevertheless, these cysts can be associated with a more complex malformation with combined anterior andposterior spina bifida.[21]

Neurenteric cyst is classically reported as a solitary lesion in the cervical region, located anterior or anterolateral to the cord.[24,25] The bony abnormalities that may be associated with neurenteric cyst are likely to involve the anterior column. Wilkins and Odum initially reviewed 47 patients with reported neurenteric cysts.[26] Later Wilkins and Rossitch added 66 more patients to this group to yield a review of 113 reported cases of neurenteric cysts. The most common reported location was cervical [63 cases], followed by thoracic [ 53 cases] and lumbosacral [ 27 cases]. Junctional cysts were reported in both locations. There was a slight male predominance of 1.8:1 with the most common location of the cyst being intradural, extramedullary, and anterior or anterolateral to the cord.[25]

Contrary to that, the cyst we report here was located on the posterior aspect ofthe spinal cord. Rauzzino, et al reported a series of 13 cases of neurenteric cysts.[27] The cysts were most commonly located dorsal to the cord in the thoracolumbar region. Also, neurenteric cyst was associated with another form of OSD in $69 \%$ of the cases. Holmes, et al reviewed 26 paediatric patients in whom they noted a high percentage of associated abnormalities. Interestingly, they also reported that $70 \%$ of their cysts occupied a dorsal location to the cord.[28]

The clinical presentation of spinal enterogenous cysts depend on the location of the lesion, and a precise diagnosis can only be made by biopsy and histological examination.[15] The more complicated lesions tend to present earlier in life. Neonates and young children often present primarily to the thoracic surgeons with cardiopulmonary problems from the mediastinal cyst.[29,30] The majority of patients present during the first decade of life with pain and myelopathy. $[29,31,32]$ This myelopathy may be entirely motor if the cyst is anteriorly located.[19] Older children and adults have similar presentations. Odd cases presenting as meningitis, either chemical.[33] or true bacterial have been reported.[9,3]

In the case reported here, there was rather atypical clinical presentation in a 56 year old man, in the form of gradually progressive neurological deterioration. The imaging studies revealed no mediastinal mass and no diverticulum or spinal cord abnormalities.
This patient had an isolated intraspinalneurenteric cyst located on the dorsal aspect of the cervical spinal cord with intramedullary extension with no associated vertebral anomalies.

Although neurenteric cysts are rare, they should be considered in the differential diagnosis of intraduralextramedullary mass lesions regardless of the age of the patient, clinical presentation or location even with theabsence of associated vertebral anomalies.

\section{REFERENCES:}

1. Mendel E, Lese GB, Gonzalez-Gomez I, et al: Isolated lumbosacral neurenteric cyst with partial sacral agenesis: case report. Neurosurg 1994, 35: 1159-1162.

2. Puusepp M: Variété rare de tératome sous-dural de la region cervicale [intestinome]: Quadriplégie-Extirpation: Guérison complete. Rev Neurol 1934, 2: 879-886.

3. Holmes GL, Trader $\mathrm{S}$, Ignatiadis $\mathrm{P}$ : Intraspinal enterogenous cysts: A case report and review of pediatric cases in theliterature. Am J Dis Child 1978, 132: 906-908.

4. Hoffman HJ, Griebel RW, Hendrick EB: Congenital spinal cord tumor in children: Neurenteric cysts. In: Symon L [ed], Advances and Technical Standards in Neurosurgery. New York, Springer-Verlag 1986, Vol. 14, pp 185-188.

5. Harriman DGF: An intraspinal enterogenous cyst. J Pathol Bacteriol 1958, 75: 413-419.

6. Klump TE: Neurenteric cyst in the cervical spinal canal of a 10- week-old boy. J Neurosurg 1971, 35: 472-475.

7. Bentley JF, Smith JR: Developmental posterior enteric remnants and spinal malformations. The split notochord syndrome. Arch Dis Child 1960, 35: 76-86.

8. Abe K, Oyama K, Mori K, et al: Neurenteric cyst of the craniocervical junction- case report. Neurol Med Chir 1999, 39: 875-880.

9. Alrabeeah A, Gillis DA, Giacomantonio M, Lau $\mathrm{H}$ : Neurenteric cysts- A spectrum. J Pediatr Surg 1988, 23: 752-754.

10. Ergun R, Akdemir G, Gezici AR, et al: Craniocervical neurenteric cyst without associated abnormalities. Pediatr Neurosurg2000, 32: 95-99.

11. Eynon-Lewis NJ, Kitchen N, Scaravilli F, Brookes GB: Neurenteric cyst of the cerebellopontine angle: case report. Neurosurg 1998, 42: 655-658.

12. Koksel T, Revesz T, Crockard HA: Craniospinal neurenteric cyst. Br J Neurosurg 1990, 4: 425-428.

13. Sampath S, Yasha TC, Shetty S, et al: Parasellar neurenteric cyst: Unusual site and histology: Case report Neurosurg1999, 44[6]: 1335-1337.

14. Weiss MA, Gebarski SS, McKeever PE: Foramen magnum neurenteric cyst causing mollaret meningitis: MR findings AJNR 1996, 17: 386-388.

15. Agnoli AL, Laun A, Schnömayr R: Enterogenous intraspinal cysts. J Neurosurg 1984, 61: 834-840.

16. Afshar F, Scholtz CL: Enterogenous cyst of the fourth ventricle: Case Report. J Neurosurg 1981, 54: 836-838.

17. Malcolm GP, Symon L, Kendall B, Pires M: Intracranial neurenteric cysts: Report of two cases. J Neurosurg 1991, 75:115-120.

18. Knight G, Griffiths T, Williams I: Gastrocytoma of the spinal cord. Br J Surg 1955, 42: 635-638. 
19. Chavda SV, Davies AM, Cassar-Pullicino VN: Enterogenous cyst of the central nervous system: A report of eight casesClin Radiol 1985, 36: 245-251.

20. Hoefnagel D, Benirschke K, Duarte J: Teratomatous cysts within the vertebral canal: Observations on the occurrence of sex chromatin. J Neurol Neurosurg Psychiatry 1962, 25: 159-164.

21. Mann KS, Khosla VK, Gulati DR, et al: Spinal neurenteric cyst. Association with vertebral anomalies, diastematomyelia, dorsal fistula, and lipoma. Surg Neurol 1984, 21: 358-362.

22. Pang D, Dias MS, Ahab-Barmada M: Split cord malformation: Part I: A unified theory of embryogenesis for double spinal cord malformations. Neurosurg 1992, 31: 451-480.

23. Palma L, Di Lorenzo N: Spinal endodermal cysts without associated vertebral or other congenital abnormalities. ActaNeurochir [Wien] 1976, 33: 283-300.

24. Gupta DK, Deodhar MC: Spilt notochord syndrome presenting with meningomyelocele and dorsal enteric fistula. J PediatrSurg 1987, 22: 382-383.

25. Wilkins RH, Rossitch JR: Intraspinal cysts. In: Pang D [ed]: Disorders of the Pediatric Spine. New York, Raven Press1995, pp 445-466.

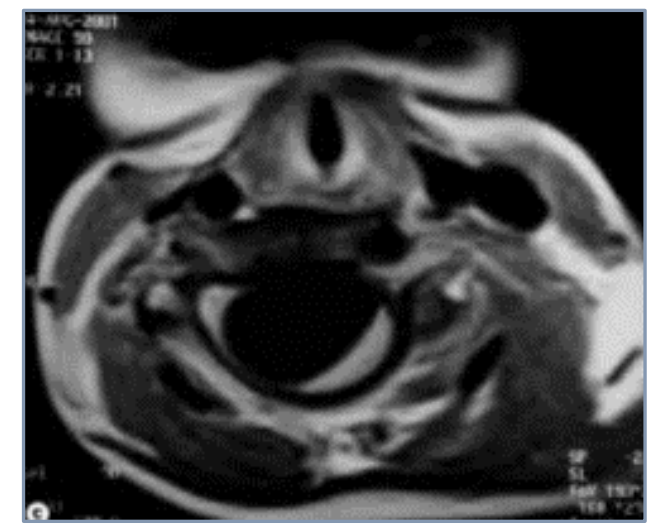

Fig. 1: Axial MRI cuts showing the lesion

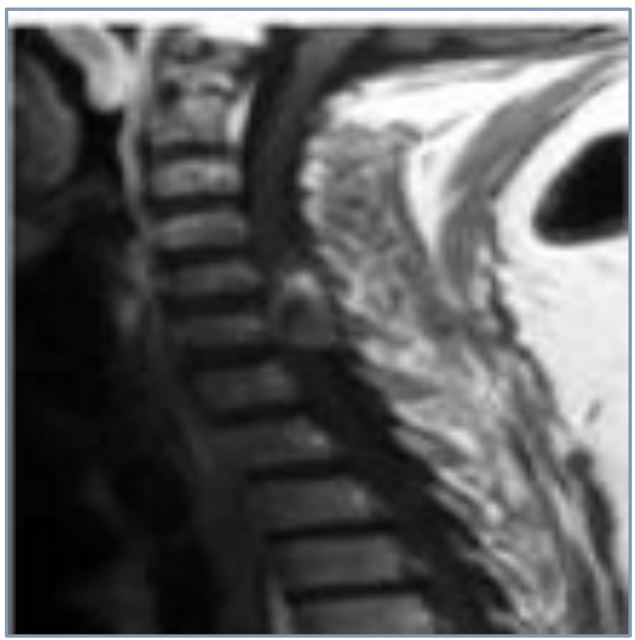

Fig. 2 Sagittal contrast enhanced MRI of cervical spine showing intradural extramedullary enhancing mass at the posterior aspect of spinal cord at level of C5- C6
26. Wilkins RH, Odum GL: Spinal intradural cysts. In: Vinken PJ, Bruyn GW [eds], Handbook of Clinical Neurology. Amsterdam, North Holland 1976, Vol. 20, pp 55-102.

27. Rauzzino MJ, Tubbs RS, Alexander E III, Grabb PA, Oakes WJ: Spinal neuroenteric cysts and their relation to more common aspects of occult spinal dysraphism. Neurosurg Focus 2001, 10[1]: 1-10.

28. Holcomb GW Jr, Matson DD: Thoracic neurenteric cyst. Surgery 1954, 35: 115-121.

29. Freund $M$, Thale A, Hutzelmann A: Radiologic and histopathologic findings in a rare case of complex occult spinal dysraphism with association of a lumbar fibrolipoma, neurenteric cyst and tethered cord syndrome. Eur Radiol 1998, 8: 624-627.

30. Superina RA, Ein SH, Humphreys RP: Cystic duplications of the oesophagus and neurenteric cysts. J Pediatr Surg 1984,19: 527-530.

31. Lazareff JA, Hoil Parra JA: Intradural neurenteric cyst at the craniovertebral junction. Childs Nerv Syst 1995, 11: 536-538.

32. Miyagi K, Mukawa J, Mekaru S, Ishikowa Y, Kinjo T, Nakasone S: Enterogenous cyst in the cervical spinal canal. JNeurosurg 1988, 68: 292-296.

33. Le Doux MS, Faye-Petersen OM, Aronin PA, Vaid YN, Pitts RM: Lumbosacral neurenteric cyst in an infant: Case report. JNeurosurg 1993, 78: 821-825.

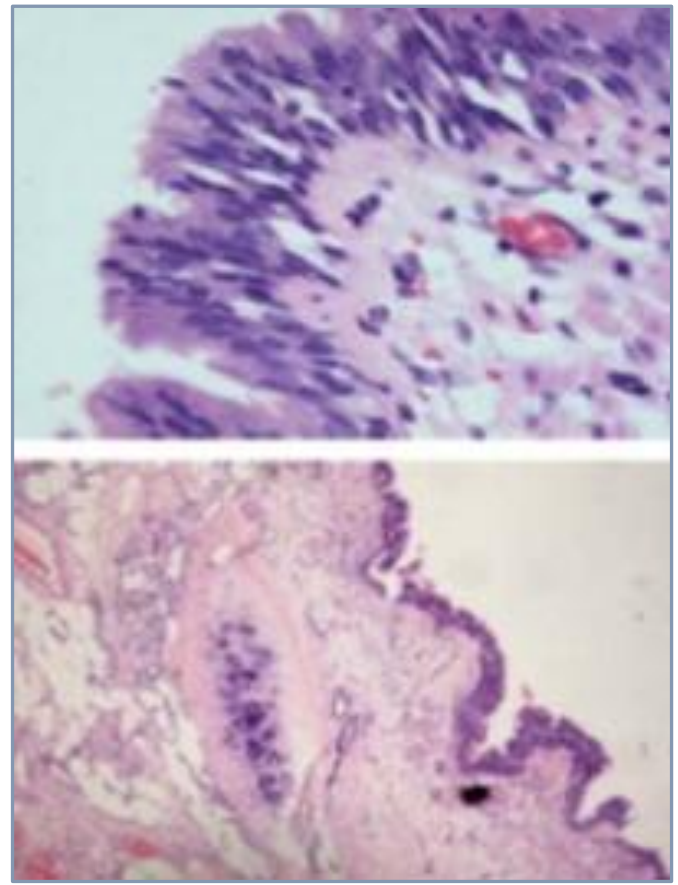

Fig. 3: Microscopic examination of the cyst, showing the typical respiratory epithelial lining. 


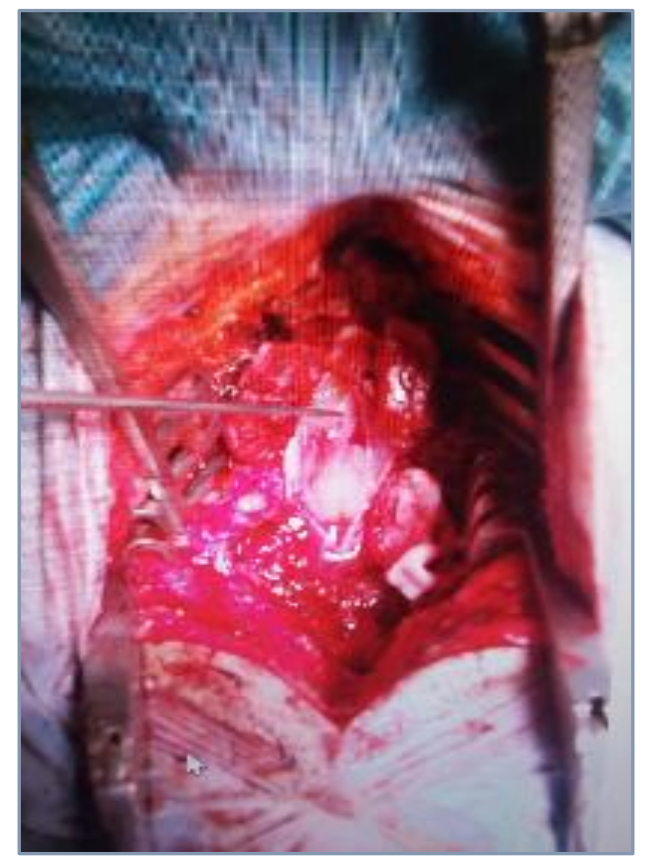

Fig. 4

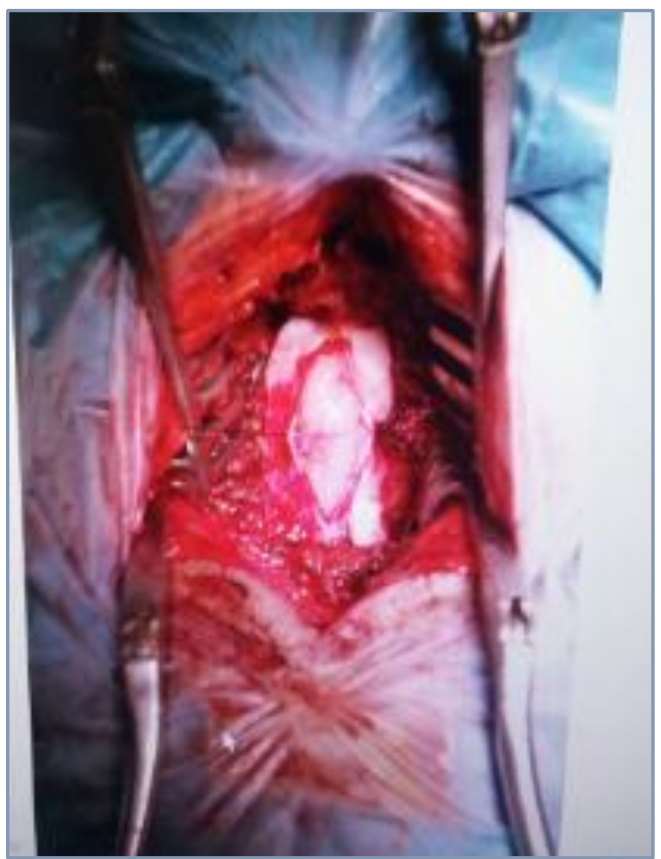

Fig. 5 